DOI: $10.14451 / 2.156 .11$

\title{
ПРАВО НА СУДЕБНУЮ ЗАЩИТУ КАК КОНСТИТУЦИОННАЯ ЦЕННОСТЬ
}

\author{
(ㄷ) 2021 Ланг Петр Петрович \\ кандидат юридических наук, доцент \\ доцент кафедры гражданского и арбитражного процесса \\ Самарский государственный экономический университет, Россия, Самара
}

В настоящей статье рассматривается основополагающее конституционное право на судебную защиту с аксиологических, ценностных позиций. В статье приводятся правовые позиции Конституционного Суда Российской Федерации относительно права на судебную защиту в иерархии права, делается акцент на фундаментальности права на судебную защиту, как обеспечивающего механизма всех иных прав и свобод человека в гражданском обществе. Уделяется внимание практической значимости рассматриваемого права, приводятся примеры судебной правоприменительной практики. Сформулировано определение права на судебную защиту как многоаспектного правового явления. Упоминается роль прав человека в качестве ценностного ориентира в правовом регулировании общественных отношений.

Ключевые слова: право на судебную защиту, правовая ценность, конститущия, судопроизводство, судебная власть.

Положения Конституции Российской Федерации императивно предоставляют каждому право осуществлять защиту своих прав и свобод всеми доступными способами, не запрещенными законом (часть 2 статьи 45). То есть любое лицо как физическое, так и юридическое свободно в выборе адекватного способа защиты своего нарушенного права. При этом существует критерий, определяющий границы указанного выбора, - способ защиты не должен быть под нормативным запретом.

Одним из основополагающих установленных законодательством способов защиты является судебная защита. Более того право каждого на судебную защиту закреплено и гарантированно на конституционном уровне (часть 1 статьи 46, статья 52 Конституции Российской Федерации).

Одновременно государство гарантирует каждому доступ к правосудию с целью защиты прав и свобод, а также с целью восстановления уже нарушенного права от посягательств кого бы то ни было, включая субъектов публичной власти. При этом следует учитывать, что человеку, его правам и свободам конституционно определена ведущая позиция в аксиологической иерархии отечественного правопорядка*. В свою очередь под правами человека следует понимать определенные нормативно структурированные свойства и особенности бытия личности, которые выражают ее свободу и являются неотъемлемыми и необходимыми способами и условиями жизнедеятельности человека, его взаимоотношений с окружающими индивидами. С аксиологических позиций права человека - это ценностный ориентир, позволяющий применять «человеческое измерение» не только к государству, праву, закону, законности, правовому порядку, но и к гражданскому обществу, поскольку степень зрелости и развития именно гражданского общества непосредственно зависит в значительной мере от состояния дел с пра-

\footnotetext{
* Algorithms of Human Activity in the Digital Age: The Problem of Preserving Traditional Values / O.J.Rybakov, J.A. Gavrilova, N.A. Kalashnikova, I. N. Falaleeva // Lecture Notes in Networks and Systems (см. в книгах). 2021. Vol. 155. Р. 558-566; Паулов П. А., Кобзарев М. А. Право на судебную защиту в контексте защиты прав и свобод человека и гражданина // Адвокатская практика. 2019. № 3. С. 21-25; ЛангП.П.Иерархия ценностей в отечественном правопорядке // Проблемы развития предприятий: теория и практика. 2018. № 4. С. 143-148; Ланг П. П. Аксиология правоприменительной практики как квинтэссенция правовой материи // Защита прав и свобод человека и гражданина: теория и практика: Сборник статей участников Международной научно-практической конференции (I Международной Школы-семинара молодых ученых-юристов), Москва, 10 сентября 2019 года / Под редакцией В.В. Казакова, К.А. Комогорцевой.- Москва: Московский финансово-юридический университет МФЮА, 2020. С. 52-57; Чернов К. Н. Право на судебное разбирательство в разумный срок как составная часть конституционного права на судебную защиту // Современное право. 2019. № 12. С. 37-39.
} 
вами человека, от объема этих прав и их практической реализации*.

Под судебной защитой следует понимать организационно-структурированную систему действий судебных органов, связанных с рассмотрением и разрешением споров, отнесенных к компетенции суда, а также отдельных действий связанных с фактическим исполнением судебных актов.

Схожую дефиницию встречаем в одной из работ Л.Ю.Грудцыной. Далее автор, обосновывая и иллюстрируя озвученную позицию, приводит примеры элементов судебной защиты. В частности, по мнению Л.Ю.Грудцыной, в качестве судебной защиты может рассматриваться как отдельное судебное действие (постановление приговора, принятие мер обеспечения иска, применение или отмена меры пресечения, вынесение частного определения), так и в целом деятельность суда по уголовному или гражданскому делу, а также деятельность всей судебной системын*.

Право на судебную защиту являются личными неотчуждаемыми правами любого человека, независимо от гражданства (подданства) последнего. Данное право на ряду с гражданами Российской Федерации в полной мере гарантируется иностранным гражданам и апатридам.

Следует отметить, что и на международном уровне также закреплено право каждого на эффективное восстановление в правах компетентными национальными судами в случаях нарушения его основных прав, предоставленных ему конституцией или законом (статья 8 Всеобщей декларации прав человека от 10 декабря 1948 года). Схожие императивы встречаются и в иных международных актах.

Конституционное право на судебную защиту осуществляется посредством обращения в компетентный суд, входящий в систему государственных судов России. При этом заинтересованное лицо имеет право в соответствии с международными договорами Российской Федерации обращаться в межгосударственные суды и правозащитные организации за защитой нарушенного права, в случае если указанным лицом исчерпаны все имеющиеся внутригосударственные (национальные) способы и средства правовой защиты. Что нашло свое отражение в положениях части 3 статьи 46 Конституции Российской Федерации.

Конституционный Суд Российской Федерации неоднократно указывал в своих решениях, что конституционное право на судебную защиту, как следует из статьи 46 (части 1 и 2) Конституции Российской Федерации,- это не только право на обращение в суд, но и возможность получения реальной судебной защиты путем восстановления нарушенных прав и свобод, которая должна быть обеспечена государством; иное не согласуется с универсальным во всех видах судопроизводства требованием эффективного восстановления в правах посредством правосудия, отвечающего критериям справедливости, умаляет и ограничивает право на судебную защиту (постановления от 2 февраля 1996 года № 4-П, от 3 февраля 1998 года № 5-П, от 28 мая 1999 года № 9-П, от 11 мая 2005 года № 5-П, от 8 июня 2015 года № 14-П, от 12 января 2021 № 1-П и др.). При рассмотрении заявлений суд не должен ограничиваться установлением формальных условий применения нормы, поскольку иное приводило бы к тому, что право на судебную защиту, закрепленное статьей 46 (часть 1) Конституции Российской Федерации, оказывалось бы существенно ущемленным (постановления от 28 октября 1999 года № 14-П, от 14 июля 2003 года № 12-П, от 12 июля 2007 года № 10-П, от 30 октября 2014 года № 26-П и др.; Определение от 9 июля 2020 года № 1644-О и др.).

Также Конституционный Суд Российской Федерации в постановлении от 02 июля 2013 года № 16-П «По делу о проверке конституционности положений части первой статьи 237 Уголовнопроцессуального кодекса Российской Федерации в связи с жалобой гражданина Республики Узбекистан Б. Т. Гадаева и запросом Курганского областного суда» отмечал, что правосудие по самой своей сути может признаваться таковым лишь при условии, что оно отвечает требованиям справедливости и обеспечивает эффективное восстановление в правах, федеральный законодатель, устанавливая порядок его отправления, обязан предусмотреть механизм (процедуру), который гарантировал бы вынесение правосудных, т.е. законных, обоснованных и справедли-

\footnotetext{
* Права человека: учебное пособие / Н. Н. Карпов, Ю.В. Нечипас, А.А. Опалева [и др.]; под ред. И. В. Гончарова; Университет прокуратуры Российской Федерации. М.: Проспект, 2020. С. 10.

** Грудцына Л.Ю.Судебная защита прав и свобод личности: теоретический аспект // Законодательство и экономика. 2003. № 8.
} 
вых, судебных решений.

При этом Конституционный Суд Российской Федерации отмечает, что ценность права на судебную защиту как важнейшей конституционной гарантии всех других прав и свобод обусловлена особым местом судебной власти в системе разделения властей и ее прерогативами по осуществлению правосудия, вытекающими из ст. ст. 10, 11 (ч. 1), 18, 118 (ч. 2), 120 (ч. 1), 125-127 и 128 (ч. 3) Конституции Российской Федерации. Именно судебная власть, независимая и беспристрастная по своей природе, играет решающую роль в государственной защите прав и свобод человека и гражданина, и именно суд окончательно разрешает спор о праве, чем предопределяется значение судебных решений как государственных правовых актов, выносимых именем Российской Федерации и имеющих общеобязательный характер (Определение Конституционного Суда РФ от 04 июня 2013 года № 882-О «Об отказе в принятии к рассмотрению запроса Законодательного Собрания Ростовской области о проверке конституционности положений пункта 2 части первой статьи 26, частей первой, второй и четвертой статьи 251 , частей второй и третьей статьи 253 Гражданского процессуального кодекса Российской Федерации и статьи 5 Закона Ростовской области «Об охране зеленых насаждений в населенных пунктах Ростовской области»).

В международных актах также делается особый акцент на необходимость формирования независимой внутригосударственной судебной системы. Согласно пункту 6 Основных принципов независимости судебных органов, одобренных Резолюциями 40/32 и 40/146 Генеральной Ассамблеи ООН от 29 ноября 1985 года и от 13 декабря 1985 года, принцип независимости судебной власти предоставляет судебным органам право и требует от них обеспечения справедливого ведения судебного разбирательства по делу, а также соблюдения прав лиц, участвующих в рассмотрении спора.

Следует констатировать, что отечественный правопорядок без каких-либо исключений придерживается, названным постулатам.

Провозглашение в Российской Федерации человека, его прав и свобод высшей ценностью обуславливает создание условий для полноценной и свободной их реализации, формирования и обеспечения действенного механизма защиты, отвечающего всем аксиологическим критериям. В указанной связи совершенно оправданно М.Г.Котельников заявляет, что по степени защищенности прав человека в значительной мере можно судить об уровне развития общества и государства в целом*.

Суды в России самостоятельны, отправляют правосудие беспристрастно и независимо, при этом подчиняются только Конституции Российской Федерации и закону (часть 1 статьи 5 Федерального конституционного закона от 31 декабря 1996 года № 1-ФКЗ «О судебной системе Российской Федерации», статья 120 Конституции Российской Федерации).

Указанная конституционная самостоятельность судебных органов обеспечивается нормативными механизмами самоуправления и самоорганизации, а также посредством законодательного установления гарантий независимости судей в России ${ }^{* *}$.

Конституция Российской Федерации также провозглашает и устанавливает равенство всех перед судом (часть 1 статьи 19).

Как отмечалось ранее, право на судебную защиту гарантируется государством каждому. Другими словами в суд за защитой нарушенного права могут обратиться не только российские граждане и их объединения, но и иностранные физические и юридические лица, международные организации, а также лица без гражданства.

В соответствии с положениями части 3 статьи 56 Конституции Российской Федерации право на судебную защиту не может быть ограничено. Конституционное установление озвученного правила имеет важное практическое значение и как следствие аксиологический потенциал.

В качестве примера можно привести постановление Арбитражного суда Поволжского округа от 26.02.2021 № Ф06-6660/2016 по делу № A65-26341/2014, в котором суд кассационной инстанции, отменяя судебные акты нижестоящих инстанций, констатировал, что при рассмотрении настоящего спора суды, ограничившись суждением о том, что требование заявителя фактически направлено на пересмотр вступив-

\footnotetext{
* Котельников М.Г. Реализация права на судебную защиту в современной России // Ленинградский юридический журнал. 2017. № 2. С. 68.

** Рыбаков О.Ю. Онтологические основания предмета конституционного права // Актуальные проблемы российского права. 2018. № 10(95). С. 120-125.
} 
ших в законную силу судебных актов по делу о несостоятельности (банкротстве) кооператива, уклонились от надлежащей оценки имеющихся доказательств и не разрешили настоящий спор по существу применительно к требованиям АПК РФ, что повлекло за собой нарушение права заявителя на судебную защиту и фактически лишило последнего гарантированного права на обжалование действий конкурсного управляющего должника. Судебная коллегия окружного суда в данном случае среди прочего отметила, что отказ в удовлетворении требований по формальным основаниям не обеспечивает должной защиты права участника гражданского оборота*.

Конституционный Суд Российской Федерации в постановлении от 13 ноября 1995 г. № 13-П «По делу о проверке конституционности части пятой статьи 209 Уголовно-процессуального кодекса РСФСР в связи с жалобами граждан Р.Н.Самигуллиной и А.А.Апанасенко» указал, что право граждан на судебную защиту относится к таким правам, которые в силу статьи 56 Конституции Российской Федерации не могут быть ограничены ни при каких условиях.

Никто не может быть лишен права на рассмотрение его дела в том суде и тем судьей, к подсудности которых оно отнесено законом (часть 1 статьи 47 Конституции Российской Федерации). Обозначенное также говорит о том, что заинтересованное лицо при обращении в суд с требованием должен соблюдать правила компетенции судов, установленные соответствующем процессуальным законодательством.

Конституционный Суд Российской Федерации в своих актах неоднократно указывал, что из права каждого на судебную защиту, как оно сформулировано в статье 46 Конституции Российской Федерации, не следует возможность выбора лицом по своему усмотрению той или иной процедуры судебной защиты, особенности которой применительно к отдельным видам судопроизводства и категориям дел определяют- ся федеральным законом (Определения от 24 ноября 2005 года № 508-О, от 19 июня 2007 года № 389-О-О, от 15 апреля 2008 года № 314-О-О).

В юридической литературе совершенно оправданно отмечается, что право на судебную защиту - многоаспектное явление в правовой материи. Обозначенный постулат основан на следующих аргументах:

- право на судебную защиту рассматривается как юридическое средство, способ обеспечения прав и свобод человека,

- право на судебную защиту представляет собой конституционный принцип либо принцип судопроизводства,

- право на судебную защиту также рассматривается в качестве субъективного права конкретного индивида, в основе которого находится мера возможного поведения**.

Обозначенное подчеркивает особо важнейшую роль права на судебную защиту в формировании правового государства и гражданского общества с учетом аксиологической, ценностной основы судебной защиты, а также органично демонстрирует особый статус рассматриваемого явления в общей системе права, принимая во внимание синергетические характеристики последней ${ }^{* * * *}$.

Резюмируя, следует констатировать, что судебная защита, осуществляемая в форме правосудия, представляет собой наивысший уровень гарантированности и обеспеченности прав и свобод субъектов правоотношений. Безусловно должный уровень отправления правосудия обуславливается высоким статусом судебных органов. И не следует забывать, что в итоге эффективность отправления правосудия непосредственно зависит от исполнимости судебных актов, вступивших в законную силу. Только при фактическом исполнении вступившего в силу судебного акта, вынесенного по итогам рассмотрения спора, можно говорить не о аморфном, а о реальном восстановлении нарушенного права.

\footnotetext{
* Постановление Арбитражного суда Поволжского округа от 26.02.2021 № Ф06-6660/2016 по делу № А6526341/2014 // https://kad.arbitr.ru.

** Песков А.А. Конституционно-правовые гарантии права на судебную защиту муниципальной собственности: дис. ... канд. юрид. наук. М., 2011. С. 43-44; Чернов К.Н. Право на судебное разбирательство в разумный срок как составная часть конституционного права на судебную защиту // Современное право. 2019. № 12. С. 37-39.

*** Лошкарев А.В. К вопросу о категории «системность права» // Вопросы экономики и права. 2016. № 92. С. 13-16; Лошкарев А.В. Синергетика в системе методов теории права: спор о применимости // Актуальные проблемы правоведения. 2015. № 1-2(45). С. 3-5.
} 


\section{Библиографический список}

1. Algorithms of Human Activity in the Digital Age: The Problem of Preserving Traditional Values / O.J. Rybakov, J. A. Gavrilova, N. A. Kalashnikova, I. N. Falaleeva // Lecture Notes in Networks and Systems (см. в книгах). 2021. Vol. 155. P. 558-566. DOI 10.1007/978-3-030-59126-7_63.

2. Грудиына Л. Ю. Судебная защита прав и свобод личности: теоретический аспект // Законодательство и экономика. 2003. № 8.

3. Котельников М.Г. Реализация права на судебную защиту в современной России // Ленинградский юридический журнал. 2017. № 2. С. 68.

4. Ланг П. П. Иерархия ценностей в отечественном правопорядке // Проблемы развития предприятий: теория и практика. 2018. № 4. С. 143-148.

5. Ланг П.П. Аксиология правоприменительной практики как квинтэссенция правовой материи // Защита прав и свобод человека и гражданина: теория и практика: Сборник статей участников Международной научно-практической конференции (І Международной Школы-семинара молодых ученых-юристов), Москва, 10 сентября 2019 года / Под редакцией В.В.Казакова, К.А. Комогорцевой.- Москва: Московский финансово-юридический университет МФЮА, 2020. С. 52-57.

6. Лошкарев А.В. К вопросу о категории «системность права» // Вопросы экономики и права. 2016. № 92. С. $13-16$.

7. Лошкарев А.В. Синергетика в системе методов теории права: спор о применимости // Актуальные проблемы правоведения. 2015. № 1-2(45). С. 3-5.

8. Паулов П.А., Кобзарев М. А. Право на судебную защиту в контексте защиты прав и свобод человека и гражданина // Адвокатская практика. 2019. № 3. С. 21-25.

9. Песков А.А. Конституционно-правовые гарантии права на судебную защиту муниципальной собственности: дис. ... канд. юрид. наук. М., 2011.

10. Права человека: учебное пособие / Н. Н. Карпов, Ю. В. Нечипас, А. А. Опалева [и др.]; под ред. И. В. Гончарова; Университет прокуратуры Российской Федерации. М.: Проспект, 2020. 296 с.

11. Рыбаков О.Ю. Онтологические основания предмета конституционного права // Актуальные проблемы российского права. 2018. № 10(95). С. 120-125.

12. Чернов K. Н. Право на судебное разбирательство в разумный срок как составная часть конституционного права на судебную защиту // Современное право. 2019. № 12. С. 37-39. 